\title{
Social Perceptions versus Economic Returns of the Higher Education: The Bologna Process in Poland
}

\author{
Marek Kwiek
}

\section{Introduction}

The Bologna process in Poland, as in Central Europe generally, was seen prior to the EU enlargement in 2004 as an effective avenue to integrate Polish universities with their Western European counterparts. Poland was among the initial signatory countries of the Bologna Declaration in 1999. In post-communist Europe, the Bologna process was often viewed as "a political option aiming at ingraining itself into European values" (Gorga 2007, 62, Tomusk 2006, Dobbins 2011). In the present study, the Bologna process is viewed through the lenses of the end product of reform initiatives it has been promoting in the last decade: in this case, a coherent system of three degrees - the bachelor, the master, and the doctorate. And in particular, it is focused on the changing social and labour market perceptions of the bachelor degree during the implementation of the Bologna process in Poland. Enhancing "employability", following Teichler (2011, 4-5), is viewed here as an increasingly relevant "additional" objective of the Bologna process, its "core" objective being enhancing mobility.

In Poland, throughout the 2000s, one of the main challenges to the implementation of the requirements of the Bologna process was the introduction of the three cycles of studies, and in particular - a clear separation of first and second degree studies. The master/bachelor split was present in Polish higher education already in the 1990s - but since its appearance, bachelor degrees had low social legitimacy and limited acceptance by the labour market as higher education credentials. The emergence of the bachelor degree 
in the 1990s was closely related to the emergence of the private sector in 1991, and its phenomenal growth in the following two decades (Kwiek 2011a, Kwiek 2010, Slantcheva, Levy 2007, Wells et al. 2007). The history of the emergence of the private sector and policy attempts to keep 90 percent of private higher education institutions at the lower, bachelor's level of studies (studia licencjackie) throughout the 1990s, as opposed to the public sector with master degrees offered (studia magisterskie), had exerted powerful influence on the implementation of the Bologna process in the 2000s. And at the core of discussions about the Bologna process, there were not ECTS points and the modularization of studies, or the internationalization of studies and student mobility, or the social dimension of studies and the recognition of diplomas: the core of Polish discussions, for a number of years, was dominated by a single theme - the future of the bachelor degree in a country in which higher education credentials, for generations, meant the master degree and in which a lower level degree was offered throughout the 1990s by, generally, inferior by quality and academic standards, private higher education (see Kwiek 2007, 2011b; Slantcheva, Levy 2007).

It was already clear in 2005 when a new Law on Higher Education was introduced that the future of the bachelor degree, a major component of Bologna reforms, would depend on its labour market acceptance. The study argues that the Bologna-related developments leading to clear separation between first and second cycle of studies have been partly successful: while the social acceptance to the first degree is still low, and the vast majority of students express their willingness to continue their studies into the second degree, the response of the labour market, as viewed through recent empirical evidence, has been very positive. Much more positive than both educational research and labour market research was showing in the last few years (see, for instance, UNDP 2007). 
The study is divided into the following sections: the present introduction; the degree structure in Poland in a European comparative context; the bachelor degree in Poland from a historical comparative perspective: legal changes and institutional transformations; the degree structure and the labour market response: review of recent empirical evidence; the bachelor degree and private higher education; and conclusions.

The 1990 Law on Higher Education - which made possible a thorough transformation of Polish higher education system after the collapse of communism in 1989 - already at that time allowed for the introduction of the bachelor degree. In the vast majority of study areas in the public sector, though, studies have been offered in two cycles only following the 2005 Law on Higher Education which was prepared, inter alia, to allow the Polish system to be adjusted to the Bologna requirements (Antonowicz 2012, Kwiek, Maassen 2012). The bachelor degree emerged in the 1990s in the private sector, and in the $2000 \mathrm{~s}$, following the Bologna process, a decade later as a mandatory degree in both sectors. The two decades of interrelations between public and private sectors in higher education, of differences in social prestige of education derived from both sectors, and changing labour market attitudes to the bachelor degree in the last few years are important to understand the Bologna-related developments in Poland. The study argues that the negative impact of low social perceptions of the bachelor degree has been decreasing and the signs of the acceptance of the degree come from the labour market.

The degree structure in Poland in a European comparative context

Is the increasing acceptance of the bachelor degree in the Polish labour market (which will be shown in more detail further in the study) an indirect product of Bologna process developments? The 
answer is positive: as long as the first degree was offered almost exclusively by the emergent private sector in higher education in the 1990s, it both had low social prestige and was refused as appropriate higher education credentials by the labour market. Recent national data tend to suggest that while the social prestige of the bachelor degree is still low (and Polish students report in comparative European surveys a very high level of willingness to continue their studies to get the master degree), its market value, viewed through the proxy of earning premiums on higher education, is quite high (OECD 2011, 138-175; for the origins of the human capital approach used today by OECD in its changing methodologies for measuring returns to education, see in particular Schultz 1963, 38-64; Hansen 1970, 157-195; Becker 1993, 59-160; Keleey 2007, 94-112; Psacharopoulos 1987; Carnoy 1995, 113-190). As Theodore W. Schultz pointed out in The Economic Value of Education: "schooling is the largest investment in human capital. ... most of the economic capabilities of people are not given at birth or at the time when children enter upon their schooling", Schultz 1963). Consequently, especially if universal fees are introduced in the Polish system in the coming years (on the critical role of fees for the future of the public/private intersectoral relations, and the survival of the private sector under declining demographics, see Kwiek 2012b), the bachelor degree may have much higher acceptance among students and graduates than previously expected in higher education literature - which would be in turn an undeniable success of the Bologna process in practical terms (see a recent comparative assessment of the employability of bachelor graduates in Europe in Schomburg, Teichler 2011, and results of scholarly-initiated graduate surveys in Schomburg, Teichler 2006 and Teichler 2007, Allen, van der Velden 2007, coming from two large-scale European research projects: CHEERS and REFLEX, or "Careers after Education - a European Research Study" and "Research into Employment and Professional Flexibility"). 
The bachelor and master degree split accepted to varying degree throughout Europe (see Schomburg, Teichler 2011) is one of the major impacts of recent changes in higher education policies coordinated at the European intergovernmental level within the Bologna process of the integration of higher education. Although initially the Bologna process was clearly an intergovernmental initiative, increasingly, in the second half of the 2000s, the role of the European Commission was becoming more and more important in it. Also the official references of the European Commission to the Bologna process made it clear that it is viewed as an important component of the (supranational, rather than intergovernmental) Lisbon Strategy, now replaced with a new Europe 2020 strategy (see Maassen, Olsen 2008, Amaral, Neave, Musselin, Maassen 2009, Kwiek, Maassen 2012, Zgaga 2006). Not only other social strategies, including Education and Training 2010 (now replaced with Education and Training 2020) and European Social Strategy (ESS) were subsumed under an economic supranational Lisbon Strategy "for more growth and jobs" - but also the intergovernmental Bologna process (an important part of which is a three-cycle structure of studies) was subsumed under overall economic strategies of the European Union. As commentators note, "the landscape of higher education is changing. Global forces are felt by all. ... Universities cannot ignore the Bologna meta-trends; it is a total package that embodies cultural and pedagogic shifts in order to embed learning outcomes, credit accumulation and transfer, qualifications frameworks at both national and supra-national levels" (Birtwistle 2009, 61). A consistent three-cycle study structure is a trademark of the Bologna process in many countries, as are intraEuropean student mobility and graduates "employability", discussed in the present study. In Poland, the introduction of the structure, including the implementation of clearly distinct first and second degrees, was perhaps the biggest challenge of the process so far (now that the structure has been introduced throughout the sys- 
tem, the most challenging area for the future seems to be the lifelong learning agenda and the implementation of the national qualifications framework, related to the EQF, the European Qualifications Framework). In some European countries, historically, the bachelor level of studies was sufficient for university graduates to enter the labour market with higher education credentials. In others, higher education credentials in the labour market meant the completion of studies at the master's level. Examples of the former countries included the UK and Ireland, as well as the USA, Canada, and Australia. Examples of the latter countries included in general those countries in which the traditional model of the university based on Humboldt's ideas was particularly strong: the Czech Republic, Poland, Germany, Austria, or Switzerland. Former Yugoslav countries used "specialist" degrees, closer to master degrees, though. The historical differences continued until recently (and still do) and were expressed most often in the level of implementation of the new degree system (generally lower for the latter countries compared with other European systems), with different speed of the implementation of the Bologna process. In Poland, the implementation of the two-tier structure of studies meant, above all, the transformation of unitary master level studies into two types: bachelor and master. But short-term master's studies (mostly two years) appeared in Poland in the public sector in the middle of 1990s and were provided mostly to graduates from the bachelor level studies in the private sector who were seeking master degrees (and they were called supplementary studies, or studia uzupelniajace).

In some countries, the division between bachelor- and masterlevel studies was widely used already in the 1990s (i.e. in the decade prior to the emergence of the Bologna process) or much earlier but the split had different meaning in different places. In AngloSaxon countries (the UK and Ireland in Europe), bachelor-level studies were leading to socially recognized higher education credentials. In such European post-communist transition countries as 
Poland, in contrast, bachelor studies were introduced in the 1990s without initial social recognition - they were not viewed as leading to complete higher education. Bachelor studies in the 1990s and at least in the first half of the 2000s were viewed by both the society at large and by the labour market as a necessary but only the first step in higher education, leading to complete higher education when master degrees are obtained. Consequently, the vast majority of bachelor-studies graduates from private sector institutions continued their education, either in public sector higher education institutions, or in those selected (less than 10\% in the 1990s) private institutions which had the legal right to offer master degrees.

Viewing the last two decades of massification processes in Central Europe (the same processes lasting at least one more decade in Western Europe), bachelor studies were especially important for those systems of higher education which wanted to expand rapidly, and in particular - to expand through the newly founded private higher education (Poland being the best example; other examples in the region include also Bulgaria and Romania; see Kwiek 2009, 2010). Slower expansion of educational systems in the 1990 s, immediately after the fall of communism, in general, occurred generally in those regional systems which did not introduce private provision in higher education on a large scale (Hungary, the Czech Republic, and the Slovak Republic).

The spread of the idea of two-cycle studies in practice in the European Higher Education Area in the 2000s was successful: between 2003 and 2007 (Trends III and Trends V reports of EUA, EUA 2003, EUA 2007), the share of responding institutions stating that they already have three-cycle structure of studies in place increased from 53\% to 82\%. Historically, while in 2003 Poland was among countries most aggressively implementing the three cycles (being among 7 countries with the level of implementation among their institutions in the $70-85 \%$ range, and with only 7 other countries scoring higher), in 2007 Poland was in exactly the same range 
of the level of implementation (again 70-85\%) but by that time it was surpassed by 19 other countries which scored $85-100 \%$ (out of 36). Thus in Poland during those years the implementation of the three cycle structure slowed down, while other countries were implementing it on a large scale. In 2008, though, Poland was again among the European leaders in implementing the Bologna process: it was among 6 European countries in which the proportion of graduates following the Bologna structures was 100\% (together with the Nordic countries - Denmark, Iceland, Norway and Sweden - and Ireland, OECD 2010, 71). The 2010 Trends VI report (EUA 2010) shows a much more homogeneous picture: Poland again belongs to the $97 \%$ of countries reporting the $85-100 \%$ range of the level of implementation of the three cycles (with only $3 \%$ of countries belonging to the other range reported, the $70-85 \%$ range, EUA 2010, 35).

Among the European transition countries, the three cycle system in 2007 was implemented in a bigger share of institutions than in Poland in such countries as Latvia, Lithuania, Slovakia, Romania and most post-Yugoslav countries, and in the same share of institutions as in Romania and the Czech Republic. On a European scale, the lowest level of implementation (0-50\%) in 2007 was in Estonia and Hungary, as well as in Sweden, Germany, Austria, Spain and Portugal (EUA 2007, 17ff.). In 2010, the implementation of the three cycle system was already in the highest range of implementation in all European countries, including all above countries lagging behind, except for three post-communist countries: Hungary, Lithuania, and Estonia (in the range of $70-85 \%$ of the reported level implementation). A recently reported implementation of the three cycle structure of studies in Europe, seems almost complete, although an EUA report admits that the picture is "more complex" and that there is the "continues coexistence of old and new structures" (EUA 2010, 35). 
Poland (following the Law on Higher Education of July 27, 2005, which introduced the three cycle structure to Polish higher education system) until 2008, was still maintaining a parallel system in which old-type 5-years-long master studies existed alongside new bachelor (3-3.5 years) and master (1.5-2 years) studies. In 2008, the enrolment in the former type of studies, except for some specific study fields like medicine or law, was abandoned (a similar case was Germany, the biggest system of higher education in Europe, in which a new system existed alongside an old one, and institutions continued to enrol students into the old degree programs, Trends $V$ 2007, 22). In more analytical terms, the international impact on the domestic policy decisions leading to the new law was through "diffusion" rather than "translation" (as Gornitzka 2006, 21 summarized the difference between the two mechanisms, "in the case of diffusion, what is imported remains unchanged"). The Bologna process, and further steps towards the European integration of higher education (e.g. the European Qualifications Framework), were imported without changes in definitions of problems or solutions. According to data provided by the Bologna process Stocktaking Report 2009, Poland was showing mixed successes in the three areas evaluated with respect to the degree system: (1) for the "stage of implementation of the first and the second cycle", Poland received score 4 (out of 5), (2) for the "access to the next cycle", Poland received score 5, and (3) for the "implementation of national qualifications framework", Poland received a low score of 2.

Economic arguments in favour of strengthening the role of first-cycle studies in higher education stress that the cost of studying shorter (3-3.5 years instead of 5 years) in systems where fees are low (or none) is lower to the taxpayer. In Europe, the role of fees in university budgets has increased substantially: between 1995 and 2008, its share increased by $50 \%$, from $8 \%$ to $12 \%$ in EU-25 (CHEPS 2010, 25; the highest share of fees in the composition of revenues in public universities in 2008 was in Ireland - 
$35 \%$, followed by Croatia - 30\%, Romania, Lithuania and Slovenia $-25 \%$ each, the UK $-24 \%$, and Poland $-22 \%$ ). Not surprisingly, systems with highest share of revenues in public institutions are either Anglo-Saxon, or post-communist transition countries. Fees could be thus combined with shorter periods of studies to either lessen the stress on public funding for higher education or to further increase enrolments in higher education in general.

The acceptance of the bachelor level of studies as a "valuable degree leading to suitable jobs in the labour market" on the part of students differs in Europe substantially but overall almost $40 \%$ of students do not agree with that statement (39\% in 2009, EC 2009). Also the evaluation of the bachelor studies on the part of academics differs substantially between European countries. So not only students' attitudes toward the bachelor/master degree split are mixed; equally mixed are attitudes of academics in Europe (and if academics themselves are not convinced about the value of the bachelor degree in the labour market, they can hardly transfer the conviction to their students and the labour market). As Harald Schomburg concluded in a recent $(2011,271)$ study on European bachelor graduates which showed that the transition rate from bachelors to masters studies among university bachelor graduates is about three quarters: "certainly, a mix of warnings by university professors about the incompleteness of Bachelor study at universities, halfhearted curricular reforms, cautious views by employers and uncertainties and high aspirations by students has led to such high rates of further studies".

Eurobarometer's survey among academic staff on Perceptions of Higher Education Reforms shows the extent to which the twotier structure of studies is still a very controversial issue in many European countries. Bachelor-degree usefulness in the labour market differs substantially both in Europe and in Central and Eastern Europe. With the statement, "first cycle graduates (Bachelor) will find suitable jobs on the labour market", on average, $39 \%$ of sur- 
veyed academics disagreed and about a half (49\%) agreed. The strongest support, not surprisingly, comes from academics from two Anglo-Saxon countries with a long tradition of short-term studies (Ireland and the UK) and, which is more surprising and shows strong differentiation between transition countries, from two postcommunist Baltic states (Latvia and Lithuania), with the highest score in Ireland ( $82 \%$ agree), followed by Latvia (75\%), the UK $(70 \%)$ and Lithuania (66\%). The strongest disbelief in the value of the bachelor degree in the labour market comes from academics in Italy, Hungary, Greece, Portugal, France, Slovakia, Austria and Estonia, where over $50 \%$ of academics disagree with the statement (51-57\%).

In Central Europe, the majority of academics still do not believe in the value of the bachelor degree in the labour market in Hungary and Slovakia (but not in the Czech Republic, with 57\% academics linking bachelor degrees with suitable jobs in the labour market). Poland is below the EU-27 average, with $42 \%$ of academics agreeing with the link (and 35\% disagreeing with the link). It is interesting to note the difference in evaluating the usefulness of the bachelor degree to the labour market by academics between the Czech Republic and Slovakia, as well as between Latvia and Lithuania on the one hand and Estonia on the other. The support of academics for the split between bachelor and master degrees also varies strongly among European countries. Poland is among those European countries in which academics are above the average in disagreeing with the statement: "The introduction of the three cycle system (the bachelor-master-doctorate) will improve (or has improved) the quality of education". In short, academics tend not believe in the success of this aspect of the Bologna process. Only in 8 countries (out of 31 studied) the disagreement is stronger than in Poland (38\%): it is above 50\% for Estonia, Slovenia, Hungary, two big Western European systems of Germany and Italy, the Netherlands and Austria. 
Retrospectively, academics in Germany, Hungary, Italy, Slovenia and Estonia agree also that it would have been better if the old onetier system was kept, without a split between bachelor and master degrees (40-53\%). In Poland, the majority of academics disagree with the statement, and about one third agrees with it (56\% and $32 \%$, respectively). Polish academics are almost evenly divided in their attitude to the statement that first cycle graduates (Bachelor) should follow a master program $(46 \%$ agree, $48 \%$ disagree, with the strongest support of over $50 \%$ in such countries as Romania, three big Western European systems of Italy, France and Spain, Portugal, Slovakia, Estonia, Latvia, and Croatia). And the disbelief is expressed in European systems in which Bologna process is reported to be implemented on a massive scale.

Students in 31 surveyed European countries (according to recent Eurobarometer's study, Students and Higher Education Reform, EC 2007) are still attached to master programs even more than academics: three-quarters of students $(75 \%)$ working towards a first cycle degree said they wanted to continue their studies. Only $18 \%$ of bachelor-level students surveyed would like to find work after graduation and never study again. Polish bachelor-level students are among those who most strongly prefer to continue studying for a second degree (75\%). In Poland, the percentage of students who are planning to find work (or return to higher education later on) after graduation is the smallest in Europe (17\% only, equal to Slovakia and Romania). In Poland, $75 \%$ of students want to continue studying for a second degree, $12 \%$ would like to find work and continue studies later on a part-time basis, and 5\% would like to find work and never study again (EC 2009, 46). Poland is also one of the eight countries in which $99-100 \%$ of students give their support for the importance of providing students with the knowledge and skills necessary to be successful in the labour market, together with Bulgaria, Romania, Lithuania, Latvia as well as Belgium, Portugal and Finland (EC 2009, 16). 
To sum up this brief statistical portrait of attitudes towards the bachelor degree in Europe: Polish students still seem not to believe in the value of bachelor degrees in the Polish labour market. They prefer to continue studying for a master degree rather than to find work. Additionally, they link very strongly higher education and employability (the link between higher education and employability is especially important in those post-communist transition countries which have strong private sector in higher education: Poland, Romania and Bulgaria, EC 2009, 41). As the study will show in further sections, strong disbelief of Polish students in the value of the bachelor degree can be contrasted with increasingly strong belief of the labour market in the degree, as viewed through the proxy of (very substantial) wage premium for higher education at the bachelor level. Also the disbelief of employers themselves (as shown by various national employers' surveys in the last decade) can be contrasted with data coming from recent labour market statistics. The bachelor degree is increasingly being accepted in practical terms, viewed through high remuneration levels compared with secondary education graduates. The Bologna process seems to have substantially increased the labour market position of graduates with the bachelor degree. Polish changes in degree structure which started in the beginning of the 1990s were reinforced by the Bologna process, and the social acceptance of the Bologna process was higher due to the presence of the two-tier structure of studies ten years before the process started. A historical note is needed here, to show the changes in more detail.

The bachelor degree in Poland from a historical perspective: legal changes and institutional transformations

The bachelor degree in Poland in social perceptions is still an inferior, professional (or vocational) degree; it is lower than the master 
degree which, and still only which, reflects complete higher education credentials. These perceptions, apart from historical reasons, are first of all a legacy of introducing a new level of studies in the new Law on Higher Education of 1990, called "vocational" (studia zawodowe) at that time. The historical legacy requires an explanation, highly relevant to the social reluctance to accept the bachelor degree as a higher education degree, and consequently to the social reluctance to accept the Bologna process with its emphasis on twotier structure of studies. The general social perception does not equal labour market perceptions anymore, though: the bachelor degree seems to be, finally, welcome by the employers, as recent (2009) national data on salaries and wages confirm - via a relatively high wage premium for higher education for bachelor degree holders.

For this current negative social perception of the bachelor degree, and for the development of vocational education at the tertiary level, of crucial importance was article 4 section 2 of the 1990 Law on Higher Education which stated that "higher education institutions may provide unitary master degree studies, higher vocational studies, and supplementary master degree studies" (emphasis mine). This article formed the legal basis for higher education institutions, both public and private, to provide various forms of vocational (defined as lower-level, not as "professional"; defined by the level of studies rather than the areas of studies, either more academic or more professional) studies at the tertiary level. The formulation was especially important for the expansion of private higher education institutions, the vast majority of which were not able to meet the academic criteria required by the Ministry of Education to offer master-level study programs. The expansion of the private sector was thus made possible by the introduction in the 1990 law of the above concept of "higher vocational studies", lasting 3 years instead of 5 years (as it was traditional for "higher education" in Poland), and leading to the vocational degree of licencjat 
or inzynier (bachelor), rather than to the academic degree of magister (master). What in Poland in 1990 made possible the expansion of the higher education system, later on became a crucial distinction between bachelor and master programs in European higher education systems in the 2000s (together with the spread of the Bologna process). But the social purpose for which first-cycle studies were introduced in Poland in 1990 still influences its relatively low social recognition. In the Polish context, vocational higher education meant the same study areas as in academic higher education but undertaken only at the first-cycle level.

The 1990 Law introduced wide institutional autonomy in both the organization of studies and the shape of study programs offered. Three-year's long vocational programs, offered in both public and private sectors, were not exactly vocational (or professional): they could be more vocational and practice-related or more academic in their focus. They could also be just as academic as study programs of first three years of studies offered in five-year unitary master programs. Only as few as 10 percent of private higher education institutions were licensed to offer master programs in the beginning in the mid-1990s; the rest of them offered bachelor programs which, no matter what their content was, no matter how academic they were, were actually termed (by the law) "vocational". The 2001 amendment to the 1990 Law on Higher Education opened the way for those private vocational institutions which were meeting the criteria to offer master programs to transform themselves into institutions regulated by the Law on Higher Education. The 2002 amendment ( $27^{\text {th }}$ July) to the 1990 Law introduced the possibility for all higher education institutions, including vocational higher education institutions, to offer studies either in the "study areas" (which was not possible for vocational institutions until then) or in "vocational study areas and specializations". In this way, the only distinction between vocational programs and academic programs was lifted: first-cycle studies both in academic 
institutions and in vocational institutions could be basically the same. There was no legal need to provide vocational education in (still legally called) vocational institutions. Finally, the 2005 Law, following the requirements of the Bologna process, introduced the concept of "first-cycle studies" instead of hitherto existing since 1990 lower-level "vocational studies", which brought about further changes. A new division of higher education institutions was introduced: academic institutions (those providing three cycles of studies) and vocational institutions (those providing two first cycles of studies only), with a negative definition of vocational institutions as those "not having the right to confer doctoral degrees", that is, not entitled to provide the third-level studies.

Consequently, since 2005, the major legal difference between academic and vocational sector in higher education has been based not on the type of studies offered (either academic or vocational) but on the academic rights possessed by higher education institutions (the only difference being between those having and those not having the right to confer doctoral degrees). The differences between vocational and academic sectors were therefore blurred further.

The degree structure and the labour market response: review of recent evidence

Both higher education and labour market have been under powerful pressures to change, both following the collapse of communism in 1989 and following joining the European Union in 2004. Social perceptions of the bachelor degree need to be contrasted with empirical evidence about its role drawn from labour market statistics. Surprisingly, still largely negative social perceptions of the bachelor degree can be contrasted with already largely positive response of the labour market to it, especially in private sector. Labour force 
in Poland in the last decade, following immense growth of higher education sector, has been increasingly better educated. The share of economically active population with higher education credentials has been substantially increasing; it has increased from 2.58 million (2003) to 4.31 million (2009), or from $15.35 \%$ to almost one quarter $(24.7 \%)$ of economically active population. Poland has been rapidly catching up with the OECD average. Higher education credentials, as in other EU economies, are closely linked to employment and unemployment levels: in 2009, as in previous years, the relationship was clear - the higher education levels, the lower chances for unemployment $(2.6 \%$ for higher education, $11.3 \%$ for secondary education and $14.3 \%$ for primary education, all data here and in subsequent paragraphs from GUS 2009). The success of the Bologna process in Poland hinges on the success of the two-tier system of studies promoted by it: if the bachelor degree is found acceptable by employers, as it seems to be the case today, the twotier system of studies may find more social acceptance. Recent empirical evidence tends to indicate that the bachelor degree has become a strong pillar of the labour market, especially in the private sector which provides about $70 \%$ of all employees in the national economy.

The well-educated segment is the only segment of Polish workforce which is increasing substantially (by 1.8 million, or $67 \%$ in 2003-2009), with the segment with general secondary education increasing only slightly in the same period (by 20\%) and all other segments decreasing. Still, the share of workforce with (combined) basic vocational and lower secondary, primary and incomplete primary education is considerable - almost $40 \%$ (39\% or 6.8 million, 2009). For both basic vocational and lower secondary education, there were decreases in 2003-2009 (from 5.77 million to 5.2 million, and from 2.21 million to 1.6 million, respectively). Compared with major UE economies, Poland's education gap has been substantially decreasing in the last decade, owing to high level of 
enrolments in higher education. Between 2000 and 2009, the number of students each year was approximately 1.58-1.95 million, and the number of graduates - about 300-400 thousand each year. While the overall level of education of the Polish population as a whole is rising steadily but is still considerably lower than the OECD average, the overall level of education of economically active population is rising considerably faster. Earlier generations with - on average - lower levels of education are leaving the labour market reaching the (lower than in major OECD economies, on average) retirement age. The domination of (combined) labour force with basic vocational and lower secondary, primary and incomplete primary education is still considerable - but much smaller than ten years ago. Every year about 400 thousand graduates from higher education enter the labour market which gradually changes the composition of the labour force. The number of higher education graduates is not expected to be higher per year, as the number of students is not expected to be higher - and in the next decade, it will be declining every year, with the lowest level, as demographic projections show, in 2025 (Kwiek 2012b).

The education level of the Polish workforce is also closely related to ownership, or the sector of employment: a public sector, which is twice as small as a private sector (about 4 million employees, as opposed to about 8 million employees in the private sector), has $30 \%$ more employees with higher education credentials. Only one-third of professionals are in the private sector employment (33\%); the rest of professionals are in the public sector (about half of whom are in public education and public healthcare, 749 thousand in the former and 284 thousand in the latter sector). What it means in practical terms is that $46 \%$ of public sector employees have higher education credentials (1.94 million out of 4.23 million), as opposed to $19 \%$ of private sector employees (only 1.58 million out of 8.13 million, 2009). 
It may mean that, effectively, education levels in the public sector can be increasing only slowly, while education levels in the private sector are much more open for further increases. The practical consequences for higher education could be that the need for higher enrolment levels is greater for those study areas which do not lead to public sector jobs (for instance, there is no need for further increases in the number of students in such study areas as teaching and related, or the humanities and related). Exactly the opposite is occurring, though, as seen through a pattern of enrolments in the last decade by fields of study.

Focusing on a particular dimension of the Bologna process in Poland, we want to contrast here generally negative social perceptions of the bachelor degree of both students, academics and the society at large (as viewed through various national and international surveys, especially of students and academics) - with an increasingly positive attitude of the Polish labour market in general, as viewed through recent national data on the wage premium for higher education. Wage premium for higher education needs to be viewed in the context of the employment structure, by occupation group, and by sector of employment. The biggest occupation group in the Polish labour force (2010) is that of professionals (2.007 million), followed by craft and related trade workers (1.751 million) and technicians and associate professionals (1.199 million). The employment structure by sector of employment shows that twothird of professionals work in the public sector (and only 683.9 thousand in the private sector), and this is the only occupation group in which the share of employees in the public sector is bigger than in the private sector. All the remaining 8 major OECD occupation groups are dominated by private sector employment.

On the one hand, transformations towards a better-educated workforce are confirmed by the increasing share of employees with higher education in the labour force. On the other hand, transformations are confirmed by increasing number of professionals in the 
labour force. The process of transformations is confirmed by newly created jobs. For instance, the number of professionals in 2008 was increasing (to 2.031 million, end of the year) and the number of workers was decreasing (from 1.791 million to 1.686 million, end of 2008). While, in the first quarter of 2008, job creation for professionals was smaller than job creation for workers, in the fourth quarter of 2008, there were more new jobs available for professionals than for workers. The trend has been continuing in 2009 and 2010, as data from the Central Statistical Office (GUS) show. The sharp increase in the last six years in the share of economically active population with higher education occurred with still high (2009) wage premium for higher education, both bachelor's and master's level, seen also by the proxy of average gross salary or average gross per-hour pay. The structure of the economically active population by sectors of employment and level of education is the following: masters-level higher education is dominant in the public sector, while bachelor's-level higher education dominates in the private sector. Bachelor's level education seems to be much more easily recognized in the private sector - while in the public sector still traditional view of complete higher education as masterlevel education prevails.

The wage premium for higher education is especially high for men in the private sector (199\% and 162\%, master's and bachelor's level), and especially low for women in the public sector $(117 \%$ and $100 \%$ ) - which reflects somehow the dominating gender structure of economically active population combined with levels of education. There seems to be no "credential inflation" (Collins 1979), no "diploma disease" (Dore 1976) and no signs of "overeducation" (Freeman 1976) in Poland at the moment, the specters of which have been haunting higher education since the 1970s. This is shown by both salaries and per hour payments. There is also strong "seniority" in salaries and wages which needs to be stressed: the real difference in average salary comes with the age - most 
strikingly in the 55-59 and 60-64 age brackets, in both public and private sectors. This may mean that the wage premium for higher education may be available mostly for older workers and not for younger, so it does not have to be available immediately after graduation. Precise differences in wages between recent bachelor and master graduates could only be shown through various types of large-scale graduate surveys which are still relatively rare in Europe and so far has been mostly academics-driven (Teichler 2011; see also a comprehensive conceptual framework to study higher education and work in Brennan, Kogan and Teichler 1996, $1-24$, and links between higher education "and the world of work" in Teichler 2009). A recent report on Poland (Grotkowska 2011, 225) does not focus on income differentials of graduates but still indicates that the income of bachelor graduates is only slightly lower than that of masters (according to the 2007 survey of about 20,000 graduates she refers to, the net hourly wage differential is only 7\%). What the report shows and what cannot be shown through labour market statistics is the lower quality of work for recent bachelor graduates: they more often work on shifts $(36 \%$ as opposed to $27 \%$ among master graduates, much more often work at night (18\% and $12 \%$, respectively), during the weekends (58\% and $44 \%$, respectively, Grotkowska 2011, 225; another recent study based on about 20,250 face-to-face interviews conducted within the Polish School Leavers Survey of 2007 shows the differentiation of labour market outcomes among graduates within higher education, especially between masters graduates and others, Baranowska 2011, 239). The Polish data are not strikingly different from other European countries surveyed as the picture is far from homogeneous: the bachelor graduates in France and Hungary earn about 30\% less while in Italy and the Netherlands they earn as much or even more on average than masters graduates (Schomburg 2011, 269). One more dimension missing from the general picture shown here (as well as from European graduate surveys in general) is a sub- 
stantial differentiation in graduate incomes across fields of studies. One future research direction is linking higher education with labour market trajectories through academic fields of study, with additional lifetime earnings different for different academic degrees viewed horizontally rather than vertically. The difference between following labour market trajectories by educational levels and by fields of study within the same educational level (e.g. at the bachelors and masters levels in different fields of study) is significant. The national average wage premium for higher education, or private internal rate of return (IRR) in higher education, or other related indicators measured over the years by the OECD, do not show the difference between fields of studies. So far, this dimension has not been systematically explored, mostly due to the lack of European data in a comparable format. And average additional lifetime earnings are substantially different for different degrees, as various national or global labour market studies show (e.g. PricewaterhouseCoopers global study on salaries related to fields of studies from 2007). While overall average additional lifetime earnings seem substantial in most countries, it is very low or almost zero for graduates in such fields of study as arts or humanities in many systems.

Researching labour market consequences of studying different fields seems fundamental to linking higher education to the labour market successes and failures (changing employment status and changing occupational status over time) both in individual EU member states and in Europe. The research literature analyzing the impact of the specific field of study (and its importance for social stratification studies) on occupational prestige, job mismatches, employment status and income is growing (see Reimer, Noelke 2008, 234). As they argue, "with increasing numbers of university graduates in the labour market, the signal value of a university degree from less-academically challenging and less selective fields like the humanities and social sciences will deteriorate". 
This is an important additional dimension of studies linking higher education to labour markets and labour market trajectories, and levels of educational attainment by field of study with wage premium for higher education by field of study (see ideas developed recently by Bernardi and Ballarino 2010). What is striking, and goes against conventional knowledge of the economic benefits from higher education in Poland, is that bachelors-level higher education seems to be already well recognized in the labour market, and well rewarded by the labour market, leading to $133.9 \%$ of salaries for bachelor degree holders generally, and to $149.3 \%$ in case of males. Which is in line with the traditional human capital theory according to which the relationship between earnings and schooling is "simple to state: more educated people enjoy a higher level of earnings than people with a lower level of education. However, people with the same level of education do have different earnings depending on their race, gender, ethnicity, ability, and social background" (Cipollone 1995, 145). The economic benefit for men with the bachelor degree is higher $(149.3 \%)$ than the economic benefit for women with the master degree (135\%, GUS 2009). Men are much higher rewarded for their higher education, regardless of the type (bachelor or master) - by 25-30 percentage points. The wage premium for higher education is also strongly related to the sector of employment: in the public sector, it is substantially lower than in the private sector of employment. While in the public sector for the master degree it is $121.2 \%$ for men and $117 \%$ for women, in the private sector it is almost 200\% (199.1\%) for men and almost $170 \%(169.4 \%)$ for women. The difference between rewards given to higher education in both sectors are related to the type of occupations prevalent in both sectors: the public sector in $47 \%$ consists of professionals, mostly in (public) education and health sectors in which higher education is much more a standard requirement than an advantage. 
This tendency is strongly confirmed by bachelor-level employees in the public sector - for women there is no reward (100\%), while for men and women combined it is only $105.3 \%$. The expectation about educational levels of employees (professionals) in the public sector is the master degree, and the bachelor degree is not viewed as an advantage, and is not financially rewarded accordingly. Higher education is rewarded much higher in the private sector: both master and bachelor levels, both men and women. Women with the bachelor degree in the private sector are higher rewarded for their education $(139.6 \%)$ than men with the master degree in the public sector (121.2\%). Overall, the differences between the two sectors are striking, and the recognition of higher education in both forms is very high: the master degree $182.2 \%(199.1 \%$ men and 169.4 women), and the bachelor degree $151.5 \%$ (162.1\% men and $139.6 \%$ women).

Returns to higher education in Poland are very high; studying is still very much financially rewarded, and working with higher education credentials in the private sector is rewarded unexpectedly high. Standard OECD statistics does not make a distinction between returns to higher education at master's and bachelor's level. But generally returns in Poland are among highest in the OECD area (no matter which OECD methodology is used). As the OECD context section about the earning premium from education points out: "high and rising premiums can indicate that more highly educated individuals are in short supply; the opposite is true for law and falling premiums. Relative earnings, trend data and the earnings premium in particular, are thus important indicators of the match between the education system and the labour market" (OECD 2011, 138). We have not discussed the social origin of bachelor and masters graduates in the present study but, as in other Central and Eastern European economies, young people originating from lower socio-economic strata tend to choose bachelor's level studies, with a stronger market orientation, in less demanding aca- 
demic fields, as pointed out in a recent large-scale comparative study on education and labour market entry in the region (Kogan et al. 2011, 336). Poland had one of the highest wage premium for higher education in general in the 2000s in Europe (together with Hungary). With a new methodology of private internal rates of return (IRR) used by OECD recently, Poland still ranked very high among OECD economies for rewards from higher education: for males, it is the third best (22.8), following the Czech Republic (the first, with 29.1) and Portugal (23.9). Hungary is fourth, with 19.8. In largest higher education systems, IRRs are below 10 (Germany, France, Spain), with higher levels for the UK (14.3) and the US (11) (OECD 2008, 196). And with still another methodology (private NPV - net present value) OECD used in 2009, Poland was relatively high on the list of OECD economies as well: it was $5^{\text {th }}$ (with the level of 147,000 USD PPP), following only Portugal, Italy, the USA and the Czech Republic, and it was $80 \%$ more than the average for the 21 economies studied (OECD 2009). Unfortunately, international comparative data for OECD countries do not seem to make a difference between the bachelor and master degrees (which is standard data for e.g. USA).

Polish empirical studies used to show until recently that wage premium for higher education for holders of bachelor degrees is close to insignificant, compared with holders of post-secondary education (holders of Matura final exams, for instance UNDP on Poland, 2007, 175ff). But most recent national data show, perhaps for the first time so clearly, that wage premium for higher education for holders of bachelor (and equivalent, e.g. engineer) degrees are also substantial, especially for men (for $\mathrm{PhD}$ and master degrees, the relationship to the average salary was $141.4 \%$ (160\% for men and $135 \%$ for women), for higher education with bachelor (and engineer) degrees, the relationship was also high $-133.9 \%$ (149.3\% for men and $119 \%$ for women; for post-secondary education, the relationship is $90.2 \%(91.4 \%$ for men and $96 \%$ for 
women). For secondary vocational education, the relationship is $74.7 \%$ (75.8 for men and only 62.2\% for women) (GUS 2009, 64). Thus employment structure statistics and labour force statistics show that (higher) education is still highly valued in the labour market and is still highly rewarded in terms of remuneration. There seems to be no recent data available about the employers' perception of the bachelor degree (in the way that such data are easily available, and internationally comparable, with regard to students' and academics' perceptions reviewed above). But perhaps a good proxy of the labour market perception is wage premium for holders of bachelor degrees - which is quite high right now. (One general reservation needs to be made, though, following the above statistical data: "learning" does not have to be "earning"; as Lauder et al. (2012, 60) stress from the perspective of what they term The Global Auction Model, "however, a graduate premium on its own tells us nothing about the demand for graduate workers in relation to concepts of the knowledge economy or of technology. It may well be that the premium is created by a decline in the wages of non-graduate labour, if graduates were then being employed to undertake work previously done by non-graduates". In the present section, we are considering the dynamics of bachelor and masters graduates earnings, and focus on the high rewards from the bachelor degree compared with the master degree - rather than on incomes and wages in general. On the most recent statement of the model, see a book on "the broken promises of education, jobs, and income", Brown et al. 2011, 1-28, 113-146, and on credentials, jobs and income as increasingly "positional goods" and on education as a "signaling device", see Hirsch 1976, Spence 1974, Collins 1974 and Blaug 1987. In empirical terms, though, the relationships between schooling and income are the same in both the human capital interpretation of education and the signaling or screening interpretation of education (as Tachibanaki 1995, 152 stressed almost two decades ago, "it is nearly impossible to identify which interpreta- 
tion is more appropriate to explain empirical evidence of the relationship between education and earnings". Also, what is troubling in the context of the human capital theory is the growing income inequality across OECD nations, or a distribution of wages across individuals which does not seem to be fully determined by the distribution of human capital, see OECD 2012 and Blair 2011, 65). The increasing acceptance of the bachelor degree in the Polish labour market seems to be an indirect product of Bologna process developments: in the 1990s the bachelor degree both had low social prestige and was refused as appropriate higher education credentials by the labour market. But recent national data tend to suggest that while the social prestige of the bachelor degree is still low, its market value is quite high, including for recent bachelor graduates. Consequently, the bachelor degree may have higher acceptance among students and graduates in the near future. The role of the Bologna process in these transformations has been substantial. There seems to be a combination of national and international forces at work which has managed to transform the national labour market position of the bachelor degree.

\section{The bachelor degree and private higher education}

Polish specificity in higher education relevant for the analysis of the bachelor/master split within Bologna process developments is that Poland has the biggest private higher education sector in Europe, with highest (34\% in 2010) enrolments. By OECD definitions, Polish private sector is "independent private sector", with income from public subsidies lower than $50 \%$ and with no publicly-funded employees. In 2009, private higher education sector had 633.100 students, $80 \%$ of them in first-cycle studies only and $82.6 \%$ of them as part-time students, and thus only about $17 \%$ as full-time students (GUS 2010, 57). The social consequences of 
such a composition of the student body in Poland for the perception of the bachelor degree are far-reaching: in the last 15 years, there were more than 1 million graduates with bachelor degrees from the (generally) low-prestige private higher education institutions. But then, in 2000s, the Bologna process came to Poland, with its pressures on two-tier structure of studies - which has reinvigorated Polish lower-level degree. Low social prestige (and low social legitimacy, see Slantcheva and Levy 2007 on Central Europe) of private higher education institutions in general is having a powerful impact on the low social prestige of current and future bachelor degree holders (and first-cycle studies) in general. Low social recognition (as testified by a large proportion of students, by European standards, wishing to continue studies at the master's level) can be contrasted with recent data drawn from the labour market statistics which indicate significant wage premium for bachelor degree holders, as discussed above. Consequently, students in Poland both plan to continue study at the master's level (highest score in Europe, EC 2009) and do undertake master's level studies, most often, in the case of private sector graduates - continue in the fee-based public sector master's programs. They do continue their studies, though, perhaps without the awareness that the labour market is already recognizing bachelor degree and rewarding its holders with substantially higher salaries/wages compared with those of secondary education graduates.

The current social attitude to bachelor-level studies promoted throughout the 2000s by the Bologna process is still determined by their initial appearance in Poland in 1991 as vocational (that is, lower-level in the Polish legal context) studies in the new private sector, seeking social recognition and social legitimacy itself. Bachelor studies for many years, until Bologna process ideas were implemented in the 2000s, were regarded as academically inferior, and provided by emergent and (largely viewed as) academically inferior private sector. Public higher education institutions, espe- 
cially universities, had negative attitudes towards bachelor level of studies for strongly cultural reasons: they offered full five-yearslong master studies, in contrast to less prestigious private sector institutions which in the 1990s were legally allowed, in their vast majority, to offer only bachelor studies. Polish public higher education institutions, especially most prestigious universities, were very reluctant in introducing bachelor degrees, and in reforming their study programs into separate bachelor and master sections. The Law on Higher Education of 2005 finally forced all higher education institutions to introduce separate study paths for both degrees (if both are offered) by 2008. The new law of 2011 merely confirmed the clear separation between study levels and introduced a learning outcomes perspective in defining study programs.

\section{Conclusions}

The promotion of first-cycle studies in Poland seems of primal importance for several interrelated reasons: the structure of the student population in which the vast majority of students chooses to continue studies at the master level, without trying to enter the labour market, is ineffective and costly to the state budget (in the case of full-time students in the public sector), as well as costly to those students who study in fee-based tracks in the public sector or in fee-based private sector. High economic returns to higher education, expressed in high wage premium for higher education for holders of both bachelor and master degrees, may indicate that Polish labour market is already recognizing the value of skills and competences achieved during first-cycle studies. Possibly, bachelor studies, still not fully recognized in social perceptions, are beginning to be recognized by the labour market, that is recognized in purely economic terms. New strategies for the development of Polish higher education until 2020 produced in 2010 do not develop 
this theme, though: there seems to be no interest in overall shortening of study periods in Poland at the moment among any of major stakeholders - government, universities, students, and parents. The future of Polish universities depends heavily on the future implementation the emergent Polish Lifelong Learning Strategy and National Quality Frameworks (related to European Qualifications Framework), so far substantially delayed. The consolidation of all skills and competences, from all levels and forms of education, into a readable and easily recognizable system is a major challenge for the future, of which the bachelor/master degree distinction is only a part today. First cycle studies may be popularized, especially in view of the economic evidence coming from the labour market, while second cycle studies may be made more selective, and possibly funded through tuition fees. The major lesson from the study is that there are periods in social and economic transformations in which social perceptions of educational credentials do not keep up with purely economic perceptions of them. While society (including students themselves) seems, by and large, to still disregard firstlevel higher education in Poland, the economy already seems to be greeting first-degree holders in the labour market. This extremely positive transformation may be viewed as a perfect illustration of Bologna process success stories in Poland.

\section{Acknowledgement}

The author gratefully acknowledges the support of the National Research Council (NCN) through its grant DEC2011/02/A/HS6/00183. 


\section{References}

Allen, Jim; van der Velden, Rolf (2011) The Flexible Professional in the Knowledge Society: New Challenges for Higher Education. Dordrecht: Springer.

Amaral, Alberto; Neave, Guy; Musseline, Christine; Maassen, Peter (eds.) (2009) European Integration and the Governance of Higher Education and Research. Dordrecht: Springer.

Antonowicz, Dominik (2012) "External Influences and Local Responses. Changes in Polish Higher Education 1990-2005." In Kwiek, Marek; Maassen, Peter (eds.) National Higher Education Reforms in a European Context: Comparative Reflections on Poland and Norway. Frankfurt and New York: Peter Lang (in press).

Attewell, Paul; Newman, Catherine S. (eds.) (2010): Growing Gaps. Educational Inequality Around the World. Oxford: Oxford University Press.

Baranowska, Anna (2011) "Does Horizontal Differentiation Make Any Difference? Heterogeneity of Educational Degrees and Labor Market Entry in Poland." In Kogan, Irena; Noelke, Clemens; Gebel, Michael (eds.) Making the Transition. Education and Labor Market Entry in Central and Eastern Europe. Stanford: Stanford University Press, pp. 216-39.

Becker, Gary (1993) Human Capital. A Theoretical and Empirical Analysis with Special Reference to Education. $3^{\text {rd }}$ edition. Chicago: the University of Chicago Press.

Bernardi, Fabrizio; Ballarino, Gabriele (2011) Higher Education Expansion, Equality of Opportunity and Credential Inflation: a European Comparative Analysis. A conference presentation at Human Capital and Employment in the European and Mediterranean Area, Bologna, 11th March 2011.

Blair, Margaret M. (2011) "An Economic Perspective on the Notion of 'Human Capital'." In Burton-Jones, Alan; Spender, J.-C. (eds.) The Oxford Handbook of Human Capital. Oxford Oxford University Press, pp. 49-70.

Blaug, Mark (1987) The Economics of Education and the Education of an Economist. Aldershot Hants: Edward Elgar.

Brennan, John; Kogan, Maurice; Teichler, Ulrich (1996) Higher Education and Work. London: Jessica Kingsley.

Birtwistle, Tim (2009) "Towards 2010 (and then Beyond) - the Context of the Bologna Process." Assessment in Education: Principles, Policy and Practice, vol. 16, no. 1, pp. 55-65.

Bologna (2009): Bologna Process Stocktaking Report 2009. By Rauhvargers, Andrejs; Deane, Cynthia; Pauwels, Wilfried. Leuven/ Louvain-la-Neuve. http://www.ond.vlaanderen.be/hogeronderwijs/bologna/conference/docume nts/Stocktaking_report_2009_FINAl.pdf 
Brown, Phillip; Lauder, Hugh; Ashton, David (2011) The Global Auction. The Broken Promises of Education, Jobs, and Incomes. Oxford: Oxford UP.

Brown, Phillip; Hesketh, Anthony (2004) The Mismanagement of Talent. Employability and Jobs in the Knowledge Economy. Oxford: Oxford University Press.

Brown, Phillip; Green, Andy; Lauder, Hugh (2001) High Skills. Globalization, Competitiveness, and Skill Formation. Oxford: Oxford University Press.

Brown, Phillip; Lauder, Hugh; Ashton, David (2008): "Education, Globalisation and the Future of the Knowledge Economy." European Educational Research Journal, vol. 7, no. 2, pp. 131-56.

Carnoy, Martin (ed.) (1995) International Encyclopedia of Economics of Education. New York: Elsevier.

CHEPS (2010) Progress in Higher Education Reform Across Europe. Governance and Funding Reform. Enschede: CHEPS (Center for Higher Education Policy Studies).

Cipollone, Piero (1995) "Education and Earnings." In Carnoy, Martin (ed.) International Encyclopedia of Economics of Education. New York: Elsevier, pp. 145-49.

Collins, Randall (1979) The Credential Society. An Historical Sociology of Education and Stratification. New York: Academic Press

Dale, Roger (2008) "Changing Meanings of 'the Europe of Knowledge' and 'Modernizing the University', from Bologna to the 'New Lisbon." European Education, vol. 39, no. 4, pp. 27-42.

Dobbins, Michael (2011) Higher Education Policies in Central and Eastern Europe. Convergence towards a Common Model? New York: Palgrave.

Dore, Ronald (1976) The Diploma Disease. Education, Qualifications and Development. London: George Allen \& Unwin.

EC (2007) Perceptions of Higher Education Reforms. Brussels: the European Commission.

EC (2009) Students and Higher Education Reform. Brussels: the European Commission.

EUA (2003) Trends in Learning Structures in European Higher Education III. A report by Sybille Reichert and Christian Tauch. Brussels: European University Association.

EUA (2007) Trends V: Universities Shaping the European Higher Education Area. By David Crosier et al. Brussels: European University Association.

Frank, Robert H. (1985): Choosing the Right Pond. Human Behavior and the Quest for Status. Oxford: Oxford UP.

Freeman, Richard B. (1976): The Overeducated America. New York: Academic Press. 
Gorga, Adriana (2008): "Where are We with the Harmonization of European Higher Education? The Case of Central and East European Countries." European Education, vol. 39, no. 4, pp. 58-68.

Gornitzka, Ase (2006) "What Is the Use of Bologna in National Reform? The Case of Norwegian Quality Reform in Higher Education." In Tomusk, Voldemar (ed.) Creating the European Area of Higher Education. Voices from the Periphery. Dordrecht: Springer, pp. 19-41.

Grotkowska, Gabriela (2011) "The Employability of Bachelor Graduates in Poland." In Schomburg, Harald; Teichler, Ulrich (eds.) Employability and Mobility of Bachelor Graduates in Europe. Key Results of the Bologna process. Rotterdam: Sense Publishers, pp. 209-28.

GUS (2009) Structure of Wages and Salaries By Occupations in October 2008. Warsaw: GUS (Central Statistical Office) (in Polish and English).

GUS (2010) Higher Education Institutions and Their Finances in 2009. Warsaw.

Hansen, W. Lee (ed.) (1970): Education, Income, and Human Capital. New York: NBER.

Hirsch, Fred (1976): Social Limits to Growth. Cambridge: Harvard UP.

Holsinger, Donald. B.; Jacob, James W. (eds.) (2008): Inequality in Education. Comparative and International Perspectives. Hong King: CERC.

Holzer, Harry J.; Lane, Julia I.; Rosenblum, David B.; Andersson, Fredrik (2011) Where are All the Good Jobs Going? What National and Local Job Quality and Dynamics May Mean for US Workers. New York: Russell Sage Foundation.

Keeley, Brian (2007) Human Capital. How What You Know Shapes Your Life. OECD: Author.

Kogan, Irena; Noelke, Clemens; Gebel, Michael (eds.) (2011) Making the Transition. Education and Labor Market Entry in Central and Eastern Europe. Stanford: Stanford University Press.

Kwiek, Marek (2006) "The Emergent European Educational Policies Under Scrutiny. The Bologna Process From a Central European Perspective." In Tomusk, Voldemar (ed.) Creating the European Area of Higher Education. Voices from the Periphery. Dordecht: Springer, pp. 87-116.

Kwiek, Marek (2007) "The European Integration of Higher Education and the Role of Private Higher Education.” In Slantcheva, Snejana; Levy, Daniel C. (eds.) Private Higher Education in Post-Communist Europe. In Search of Legitimacy. New York. Palgrave/ Macmillan, pp. 119-32.

Kwiek, Marek (2008) “"Accessibility and Equity, Market Forces and Entrepreneurship: Developments in Higher Education in Central and Eastern Europe." Higher Education Management and Policy, vol. 20, no. 1, pp. 89110. 
Kwiek, Marek (2009a) "The Two Decades of Privatization in Polish Higher Education. Cost-Sharing, Equity and Access." In Knight, Jane (ed.) Financing Higher Education: Equity and Access. Rotterdam/Boston/Taipei: Sense Publishers, pp. 149-68.

Kwiek, Marek (2009b) "The Changing Attractiveness of European Higher Education." In Kehm, Barbara; Huisman, Jeroen; Stensaker, Bjorn (eds.) The European Higher Education Area: Perspectives on a Moving Target. Rotterdam/Boston/Taipei: Sense Publishers, pp. 107-24.

Kwiek, Marek (2010) "Creeping Marketization: Where Polish Private and Public Higher Education Sectors Meet.” In Brown, Roger (ed.) Higher Education and the Market. New York: Routledge, pp. 135-46.

Kwiek, Marek (2011a) "The Public-Private Dynamics in Polish Higher Education. Demand-Absorbing Private Growth and Its Implications." Higher Education Forum, no. 8., pp. 121-47.

Kwiek, Marek (2011b) "Universities and Knowledge Production in Central Europe." In Temple, Paul (ed.) Universities in the Knowledge Economy. Higher Education Organisation and Global Change. New York: Routledge, pp. 176-95.

Kwiek, Marek (2012a) "Universities, Regional Development and Economic Competitiveness: the Polish Case." In Pinheiro, Romulo; Benneworth, Paul; Jones, Glen (eds.) Universities and Regional Development. A Critical Assessment of Tensions and Contradictions. New York: Routledge, pp. 69-85.

Kwiek, Marek (2012b) "Public-Private Intersectoral Competition: Fees and Declining Demographics." Compare: A Journal of Comparative and International Education, vol. 42, issue 1, pp. 153-157.

Kwiek, Marek; Maassen, Peter (eds.) (2012) National Higher Education Reforms in a European Context: Comparative Reflections on Poland and Norway. Frankfurt and New York: Peter Lang.

Kwiek, Marek; Arnhold, Nina (2011) "Enabling Smart Growth for Poland Through Education and Skills Supply." In Europe 2020 Poland. Fueling Growth and Competitiveness in Poland Through Employment, Skills, and Innovation, volume 2. Technical Report. Washington DC: World Bank, pp. 97-130.

Lauder, Hugh; Young, Michael; Daniels, Harry; Balarin, Maria; Lowe, John (eds.) (2012) Educating for the Knowledge Economy? Critical Perspectives. London and New York: Routledge.

Maassen, Peter; Olsen, Johan P. (eds.) (2007) University Dynamics and European Integration. Dordrecht: Springer.

Maassen, Peter; Musselin, Christine (2009) "European Integration and the Europeanisation of Higher Education." In Amaral, Alberto; Neave, Guy; Mus- 
seline, Christine; Maassen, Peter: European Integration and the Governance of Higher Education and Research. Dordrecht: Springer.

Neave, Guy; Peter Maassen (2007) "The Bologna process: An Intergovernmental Policy Perspective." In Maassen, Peter; Olsen, Johan P. (eds.) University Dynamics and European Integration. Dordrecht: Springer.

OECD (2008) Education at a Glance 2008. OECD Indicators. Paris: OECD.

OECD (2009) Education at a Glance 2009. OECD Indicators. Paris: OECD.

OECD (2010) Education at a Glance 2010. OECD Indicators. Paris: OECD.

OECD (2011) Education at a Glance 2011. OECD Indicators. Paris: OECD.

Ortiz, Luis; Kucel, Aleksander (2008) "Do Fields of Study Matter for OverEducation?" International Journal of Comparative Sociology, vol. 49, no. 4-5.

Psacharopoulos, George, ed. (1987) Economics of Education. Research and Studies. Oxford: Pergamon Press.

Reimer, D.; C. Noelke (2008) "Labor Market Effects of Field of Study in Comparative Perspective. An Analysis of 22 European Countries." International Journal of Comparative Sociology; vol. 49, no. 4-5, pp. 305-27.

Slantcheva, Snejana; Levy, Daniel C. (eds.) (2007) Private Higher Education in Post-Communist Europe. In Search of Legitimacy. New York: Palgrave/Macmillan.

Schomburg, Harald (2011) "Employability and Mobility of Bachelor Graduates: The Findings of Graduate Surveys in Ten European Countries on the Assessment of the Impact of the Bologna Reform". In Schomburg, Harald; Teichler, Ulrich (eds.) Employability and Mobility of Bachelor Graduates in Europe. Key Results of the Bologna Process. Rotterdam: Sense Publishers, pp. 253-74.

Schomburg, Harald; Teichler, Ulrich (2006) Higher Education and Graduate Employment in Europe. Results from Graduate Surveys from Twelve Countries. Dordrecht: Springer.

Schomburg, Harald; Teichler, Ulrich (eds). (2011) Employability and Mobility of Bachelor Graduates in Europe. Key Results of the Bologna process. Rotterdam: Sense Publishers.

Schultz, Theodore W. (1963) The Economic Value of Education. New York: Columbia University Press.

Shavit, Y.; Arum, R.; Gamoran, A. (eds.) (2007) Stratification in Higher Education. A Comparative Study. Stanford: Stanford University Press.

Spence, A. Michael (1974) Market Signaling: Informational Transfer in Hiring and Related Screening Processes. Cambridge, MA: Harvard University Press. 
St. John, Edward P.; Hu, Shouping; Fisher, Amy S. (2011) Breaking Through the Access Barrier. How Academic Capital Formation Can Improve Policy in Higher Education. New York: Routledge.

Tachibanaki, Toshiaki (1995) "Education, Occupation, and Earnings." In Carnoy, Martin (ed.) International Encyclopedia of Economics of Education. New York: Elsevier, pp.145-49.

Teichler, Ulrich (ed.) (2007) Careers of University Graduates. Views and Experiences in Comparative Perspectives. Dordrecht: Springer.

Teichler, Ulrich (2009) Higher Education and the World of Work. Conceptual Frameworks, Comparative Perspectives, Empirical Findings. Rotterdam/Taipei: Sense Publishers.

Teichler, Ulrich (2011) "Bologna - Motor or Stumbling Block for the Mobility and Employability of Graduates?" In Schomburg, Harald; Teichler, Ulrich (eds.) Employability and Mobility of Bachelor Graduates in Europe. Key Results of the Bologna process. Rotterdam: Sense Publishers, pp. 3-42.

Tomusk, Voldemar (2004) The Open World and Closed Societies. Essays on Higher Education Policies "In Transition". New York: Palgrave.

Tomusk, Voldemar ed. (2006) Creating the European Area of Higher Education. Voices from the Periphery. Dordrecht: Springer.

UNDP (2007) Edukacja dla pracy. Raport o Rozwoju Społecznym Polska 2007 (Education for Work. A Report on Social Development - Poland 2007). Ed. by Sztanderska, Urszula. Warszawa: UNDP.

Wells, Peter James; Sadlak, Jan; Vlasceanu, Lazar (eds.) (2007) The Rising Role and Relevance of Private Higher Education in Europe. Bucharest, Romania: UNESCO-CEPES (European Centre for Higher Education).

Zgaga, Pavel (2006) Looking out: The Bologna Process in a Global Setting. On the "External Dimension" of the Bologna Process. Oslo: Norwegian Ministry of Education and Research. 